\title{
Natural Products Published in 2009 from Plants Traditionally Used to Treat Malaria
}

Authors

Affiliation
Joanne Bero, Joëlle Quetin-Leclercq

Pharmacognosy Research Group, Louvain Drug Research Institute, Université Catholique de Louvain, Brussels, Belgium

\author{
Key words \\ - antiplasmodial activity \\ - plants \\ - malaria \\ - Plasmodium falciparum
}

received June 15, 2010

revised July 29, 2010

accepted Sept. 9, 2010

\section{Bibliography}

Dol http://dx.doi.org/ 10.1055/s-0030-1250405

Published online October 19, 2010

Planta Med 2011; 77: 631-640

(c) Georg Thieme Verlag KG

Stuttgart $\cdot$ New York .

ISSN 0032-0943

\section{Correspondence}

Joanne Bero

Pharmacognosy Research Group Louvain Drug Research Institute Université Catholique de Louvain

Avenue E. Mounier 72

1200 Brussels

Belgium

Phone: + 3227647292

Fax: + 3227647293

Joanne.bero@uclouvain.be

\section{Abstract \\ $\nabla$}

Malaria is a major parasitic disease and is responsible for almost one million deaths each year in Africa. There is an urgent need to discover new active compounds. Nature and particularly plants are a potential source of new antimalarial drugs since they contain a quantity of metabolites with a great variety of structures and pharmacological activities. This review covers the compounds with

\section{Introduction}

$\nabla$

There were an estimated 247 million malaria cases among 3.3 billion people at risk in 2006, causing nearly a million deaths, mostly of children under 5 years (WHO, 2008). This disease, transmitted by an Anopheles mosquito, is caused by Plasmodium species. The parasite is now resistant to a number of antimalarials but plants can offer new metabolites with an original mode of action such as artemisinin from Artemisia annua which can be active on resistant strains. In this review, all antiplasmodial metabolites new or already known and isolated from plants to treat malaria and published in 2009 are described and organised according to their phytochemical classes. All the activities were determined in vitro on Plasmodium falciparum strains unless specified and bioguided fractionation was also based on this antimalarial test. Activities were assessed on different strains among which some are chloroquine sensitive (NF54, 3D7, D6, F32, D10, Ghana, TM4), chloroquine resistant (FcB1, W2, FCM29, Dd2, FCR-3) and/or multidrug resistant (K1) strains, to find effective compounds on resistant malaria. We considered that those having an $\mathrm{IC}_{50} \leq 11 \mu \mathrm{M}$ may have some interest for further development, while those with a lower activity were less interesting. That is why we only give structures for these promising compounds, the others are cited antiplasmodial activity isolated from plants which have been published during 2009 organized according to their phytochemical classes. Details are given for substances with $\mathrm{IC}_{50}$ values $\leq 11 \mu \mathrm{M}$. Sixty-seven references are identified.

Supporting information available online at http://www.thieme-connect.de/ejournals/toc/ plantamedica

in tables. Compounds tested in vivo are also cited. We also analysed the phytochemical classes of these metabolites published in 2009 and the families of plant from which they were isolated and compared these data with those of compounds published from 2005 to 2008. Other reviews already exist for compounds published before 2005 [1-7], or before 2009 [8-10].

\section{Phenolic Derivatives \\ $\nabla$}

Flavonoid derivatives ( $\odot$ Fig. 1)

The hexane extract of ground fruits of Neuraputia magnifica var. magnifica (Engl.) Emmerich (Rutaceae) was fractionated to obtain 2'-hydroxy3,4,4',5,6'-pentamethoxychalcone (1) which exhibited an antiplasmodial activity with an $\mathrm{IC}_{50}$ of $6.9 \mu \mathrm{M}$ on 3D7 [11].

A new $\beta$-hydroxydihydrochalcone named (S)-elatadihydrochalcone (2) was isolated from the seedpods of Tephrosia elata Deflers. (Leguminosae) and showed antiplasmodial activity with $\mathrm{IC}_{50}$ values of 7.9 and $15.5 \mu \mathrm{M}$, respectively, on D6 and W2 [12].

A new isoprenylated flavone, artopeden A (3) was isolated from the bark of Artocarpus champeden Spreng. (Moraceae) and showed antiplasmodial activity with an $\mathrm{IC}_{50}$ of $0.11 \mu \mathrm{M}$ against 3D7 [13]. 
<smiles>COc1cc(O)c(C(=O)/C=C/c2cc(OC)c(OC)c(OC)c2)c(OC)c1</smiles><smiles>COc1cc2c(c(O)c1C(=O)CC(O)c1ccccc1)C=CC(C)(C)O2</smiles><smiles>COc1ccc(-c2oc3cc(O)cc(O)c3c(=O)c2OC)cc1</smiles>

Fig. 1 Flavonoid derivatives with moderate or promising activity in vitro against various strains of Plasmodium falciparum.

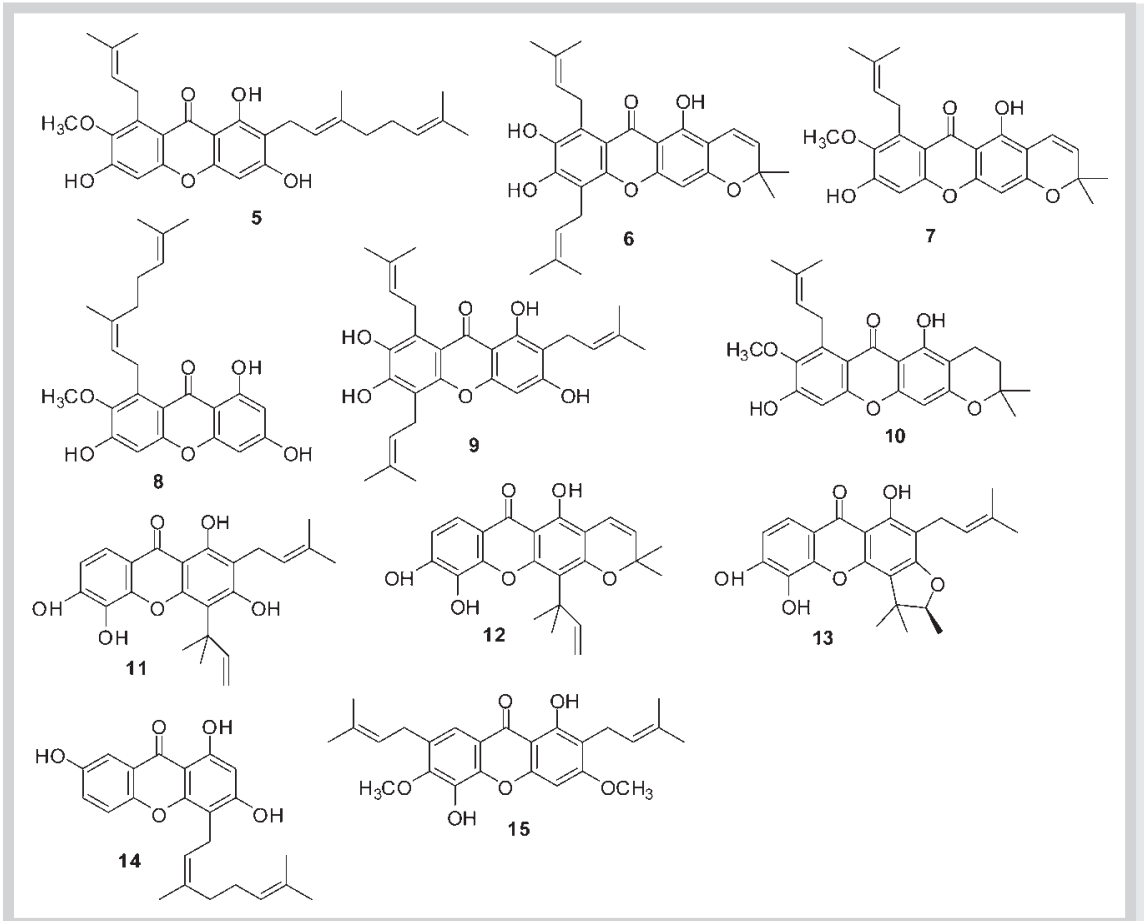

Fig. 2 Xanthones with moderate activity in vitro against various strains of Plasmodium falciparum.

Baccharis dracunculifolia D.C. (Asteraceae) contains ermanin (4) having an $\mathrm{IC}_{50}$ of $8.3 \mu \mathrm{M}$ on D6 and of $7.0 \mu \mathrm{M}$ on W2 [14].

\section{Xanthones ( $\odot$ Fig. 2)}

Two new xanthones, butyraxanthones A and B (5 and $\mathbf{6}$ ), were isolated from the stem bark of Pentadesma butyracea Sabine (Clusiaceae), together with four known xanthones: xanthone I (7), rubraxanthone (8), garcinone E (9) and 3-isomangostin (10). They exhibited antiplasmodial activity against $\mathrm{FCB} 1$ with $\mathrm{IC}_{50}$ values of, respectively, 6.3, 5.8, 4.7, 8.3, 6.0 and $7.6 \mu \mathrm{M}$ but were cytotoxic against a human breast cancer cell line (MCF-7) with $\mathrm{IC}_{50}$ values of, respectively, 7.3, 7.1, 9.6, 6.3, 3.2 and $2.9 \mu \mathrm{M}$ [15].

Three xanthones: gerontoxanthone I (11), macluraxanthone (12) and formoxanthone $C$ (13) were isolated from the stem bark of Cratoxylum maingayi Dyer (Clusiaceae) and another one [fuscaxanthone E (14)] from the fruits of Cratoxylum cochinchinense Blume (Clusiaceae). They displayed antimalarial activity against $\mathrm{K} 1$ with $\mathrm{IC}_{50}$ values of $4.2,3.4,3.0$ and $7.9 \mu \mathrm{M}$, respectively [16]. A new xanthone, 1,5-dihydroxy-3,6-dimethoxy-2,7-diprenylxanthone (15) was obtained from Garcinia griffithii T. Anderson (Clusiaceae). It showed antiplasmodial activity with an $\mathrm{IC}_{50}$ of $7.3 \mu \mathrm{M}$ on a Ghana strain [17].

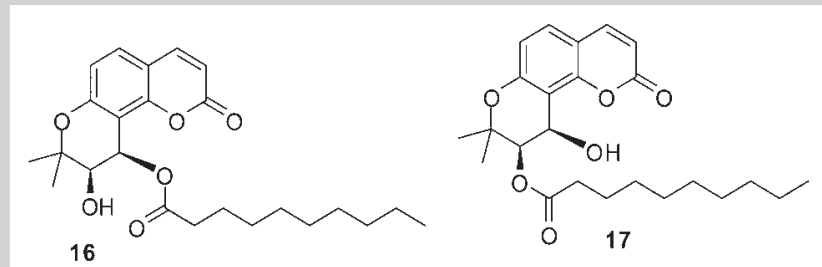

Fig. 3 Coumarins with moderate or promising activity in vitro against various strains of Plasmodium falciparum.

\section{Coumarins (- Fig. 3)}

The methanolic extract of the rhizomes of Angelica purpuraefolia T.H. Chung (Apiaceae) was investigated and two natural khellactones, (+)-4'-decanoyl-cis-khellactone (16) and (+)-3'-decanoylcis-khellactone (17) were isolated. These two compounds were evaluated for antiplasmodial activities and showed growth inhibitory activity against D10 with $\mathrm{IC}_{50}$ values of 1.5 and $2.4 \mu \mathrm{M}$, respectively [18]. 


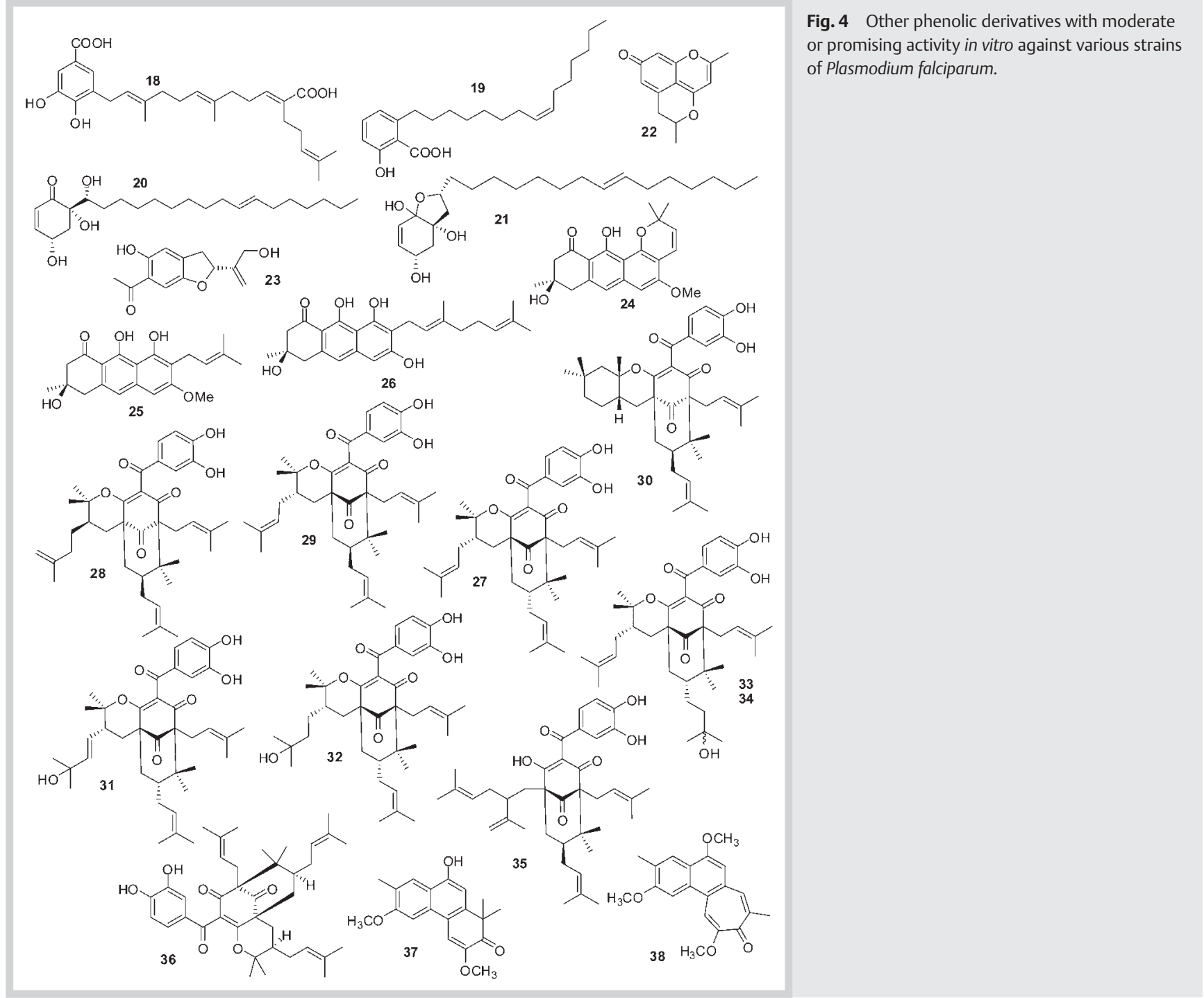

\section{Other phenolic derivatives ( $\odot$ Fig. 4)}

Compound 18 was isolated from the dichloromethane extracts of the leaves of Piper heterophyllum Ruiz \& Pav. and P. aduncum L. (Piperaceae) and exhibited activity with an $\mathrm{IC}_{50}$ of $7.0 \mu \mathrm{M}$ on F32 [19].

The petroleum ether extract of Viola websteri Hemsl. (Violaceae) was investigated and the main antiplasmodial compound was 6(8'Z-pentadecenyl)-salicylic acid (19) with an $\mathrm{IC}_{50}$ of $10.1 \mu \mathrm{M}$ (D10). Given intraperitoneally, 19 showed in vivo a $63 \%$ suppression of parasitemia in P. berghei infected mice treated at $10 \mathrm{mg} /$ $\mathrm{kg} /$ day. When used prophylactically a suppression of $70.1 \%$ at the same dose was recorded $[20,21]$.

The bioassay-guided purification of the $\mathrm{CH}_{2} \mathrm{Cl}_{2}$ extract of the bark of Tapirira guianensis Aubl. (Anacardiaceae) led to the isolation of two cyclic alkyl polyol derivatives: 4,6,2'-trihydroxy-6-[10'(Z)heptadecenyl]-1-cyclohexen-2-one (20) and 1,4,6-trihydroxy1,2'-epoxy-6-[10'(Z)-heptadecenyl]-2-cyclohexene (21). The antiplasmodial activity of a mixture of these two compounds showed an $\mathrm{IC}_{50}$ of $4.7 \mu \mathrm{M}$ on F32 and $5.4 \mu \mathrm{M}$ on FcB1 [22].

A new chromone, 10,11-dihydroanhydrobarakol (22), which showed antiplasmodial activity against $3 \mathrm{D} 7\left(\mathrm{IC}_{50}=2.3 \mu \mathrm{M}\right)$, was isolated from flowers of Cassia siamea Lam. (Caesalpinaceae) [23].
Studies on Baccharis dracunculifolia D.C. (Asteraceae) allowed the isolation of viscidone (23) which showed an $\mathrm{IC}_{50}$ of $8.1 \mu \mathrm{M}$ on D6 and of $9.8 \mu \mathrm{M}$ on W2 [14].

Three phenolic compounds, vismione B (24), F (25) and E (26) were isolated from the fruits of Cratoxylum cochinchinense Blume (Clusiaceae) and displayed antimalarial activity against $\mathrm{K} 1$ with $\mathrm{IC}_{50}$ values of $1.86,4.76$ and $10.97 \mu \mathrm{M}$, respectively [16].

Acyl phloroglucinols [isogarcinol (27), cycloxanthochymol (28), 7epi-isogarcinol (29), coccinone A (30), B (31), C (32), D (33) and E (34), and 7-epi-garcinol (35)] from Moronobea coccinea Aubl. (Clusiaceae) exhibited an activity with $\mathrm{IC}_{50}$ values of $3.5,2.1,5.1,4.3$, 5.5, 9.0, 7.0, 4.9 and $10.1 \mu \mathrm{M}$, respectively, on FcB1 [24].

Isoxanthochymol (36) was obtained from Garcinia griffithii T. Anderson (Clusiaceae) and showed antiplasmodial activity with an $\mathrm{IC}_{50}$ of $4.5 \mu \mathrm{M}$ on a Ghana strain but it was also cytotoxic against MRC-5 cells $\left(\mathrm{IC}_{50}=7.5 \mu \mathrm{M}\right)$ [17].

A new phenanthrenone, 9-O-demethyltrigonostemone (37), and a new phenanthropolone (38) were isolated from the roots of Strophioblachia fimbricalyx Boerl. (Euphorbiaceae) and displayed antiplasmodial activity ( $\mathrm{IC}_{50}$ values of 8.7 and $9.9 \mu \mathrm{M}$, respectively) against K1 [25]. 


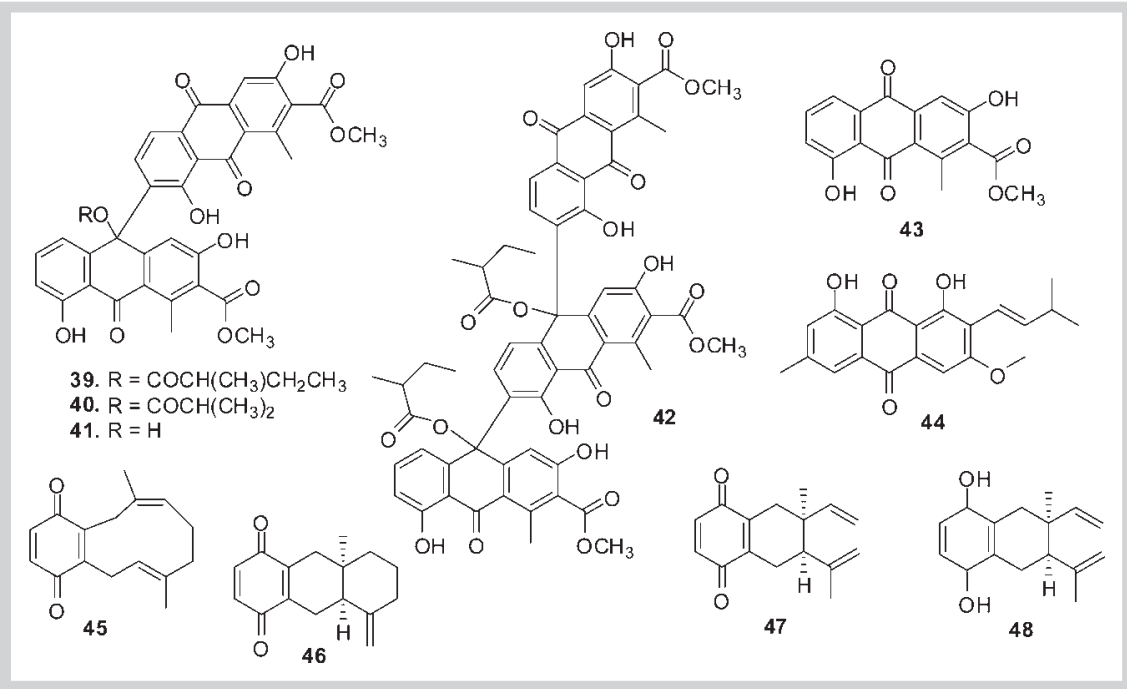

Fig.5 Quinones and derivatives with moderate or promising activity in vitro against various strains of Plasmodium falciparum.

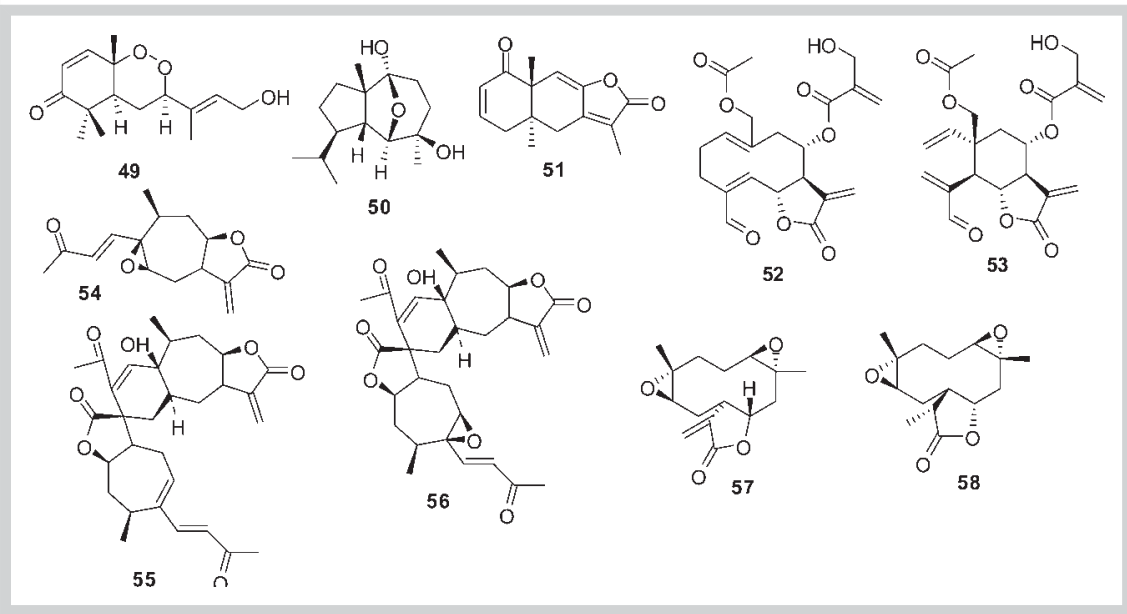

Fig. 6 Sesquiterpenes with moderate or promising activity in vitro against various strains of Plasmodium falciparum.

\section{Quinones and Derivatives ( $\odot$ Fig. 5)}

Bioassay-guided fractionation of an ethanol extract of the bark of Scutia myrtina Kurz (Rhamnaceae) led to the isolation of three new anthrone-anthraquinones dimers, scutianthraquinones $\mathrm{A}$ (39), B (40) and C (41), one new bisanthrone-anthraquinone trimer, scutianthraquinone $\mathrm{D}(\mathbf{4 2})$ and the known anthraquinone, aloesaponarin I (43). These compounds exhibited antiplasmodial activities with $\mathrm{IC}_{50}$ values of $1.23,1.14,3.14,3.68$ and $5.58 \mu \mathrm{M}$, respectively, on Dd2 and 1.2, 5.4, 15.4, 5.6 and $>50 \mu \mathrm{M}$, respectively, on FCM29 [26].

A phytochemical study of the stem bark of Vismia laurentii De Wild. (Clusiaceae) resulted in the isolation of a known compound, vismiaquinone $A(44)$ which showed antimalarial activity of $1.42 \mu \mathrm{M}$ against W2 [27].

A new compound named globiferin (45) was isolated from root extracts of Cordia globifera W.W. Sm. (Boraginaceae) with cordiachrome B (46), cordiachrome C (47) and cordiaquinol C (48). Antimalarial activities $\left(\mathrm{IC}_{50}\right)$ were 8.7, 6.2, 0.8 and $1.2 \mu \mathrm{M}$, respectively, on K1 [28].

\section{Terpenoids \\ $\nabla$}

Sesquiterpenes (๑ Fig. 6)

Okundoperoxide (49) was isolated by bioassay-guided fractionation from extracts of roots of Scleria striatonux de Wild. (Cyperaceae) and possessed $\mathrm{IC}_{50}$ values of $1.8,1.8,5.6,4.9 \mu \mathrm{M}$, respectively, on W2, D6, K1, NF54 [29].

An antiplasmodial bioguided investigation of the EtOAc extract of the aerial parts of Teucrium ramosissimum Desf. (Lamiaceae) led to the isolation of homalomenol C (50). Its $\mathrm{IC}_{50}$ was $4.7 \mu \mathrm{M}$ on FcB1 [30].

The ethyl acetate extract of Siphonochilus aethiopicus (Schweinf.) B.L. Burtt (Zingiberaceae) rhizomes was fractionated to isolate a novel furanoterpenoid (51). This compound showed antiplasmodial activity with $\mathrm{IC}_{50}$ values of 13.9 and $7.2 \mu \mathrm{M}$, respectively, on D10 and K1 [31].

Bioassay-guided fractionation led to the isolation of two new sesquiterpene lactones (52 and 53) from an extract of Distephanus angulifolius (DC.) H. Rob. \& B. Kahn (Asteraceae). The isolated compounds showed $\mathrm{IC}_{50}$ values of 1.9 and $1.55 \mu \mathrm{M}$ on D10 and 3.24 and $2.10 \mu \mathrm{M}$ on $\mathrm{W} 2$, respectively [32].

Bioactivity-guided fractionation of the dichloromethane extract of Xanthium brasilicum Vell. (Asteraceae) resulted in the isolation of three bioactive sesquiterpene lactones: 8 -epixanthatin $1 \beta, 5 \beta$ epoxide (54), and the dimers pungiolide $A(55)$ and $B(56)$. They showed $\mathrm{IC}_{50}$ values of $6.5,5.0$ and $6.5 \mu \mathrm{M}$ against $\mathrm{K} 1$ [33]. 

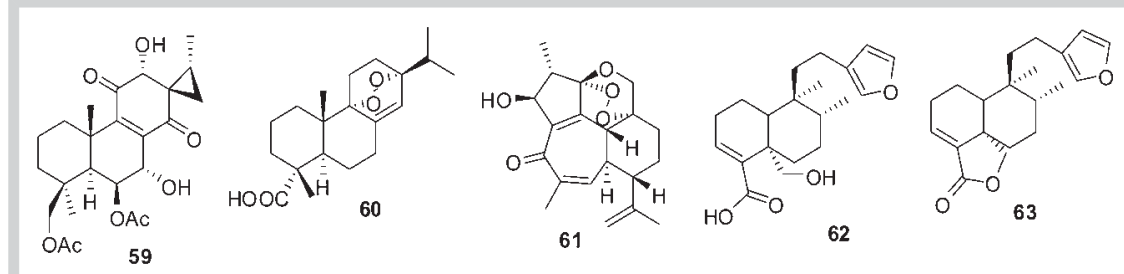

Fig. 7 Diterpenes with moderate activity in vitro against various strains of Plasmodium falciparum.

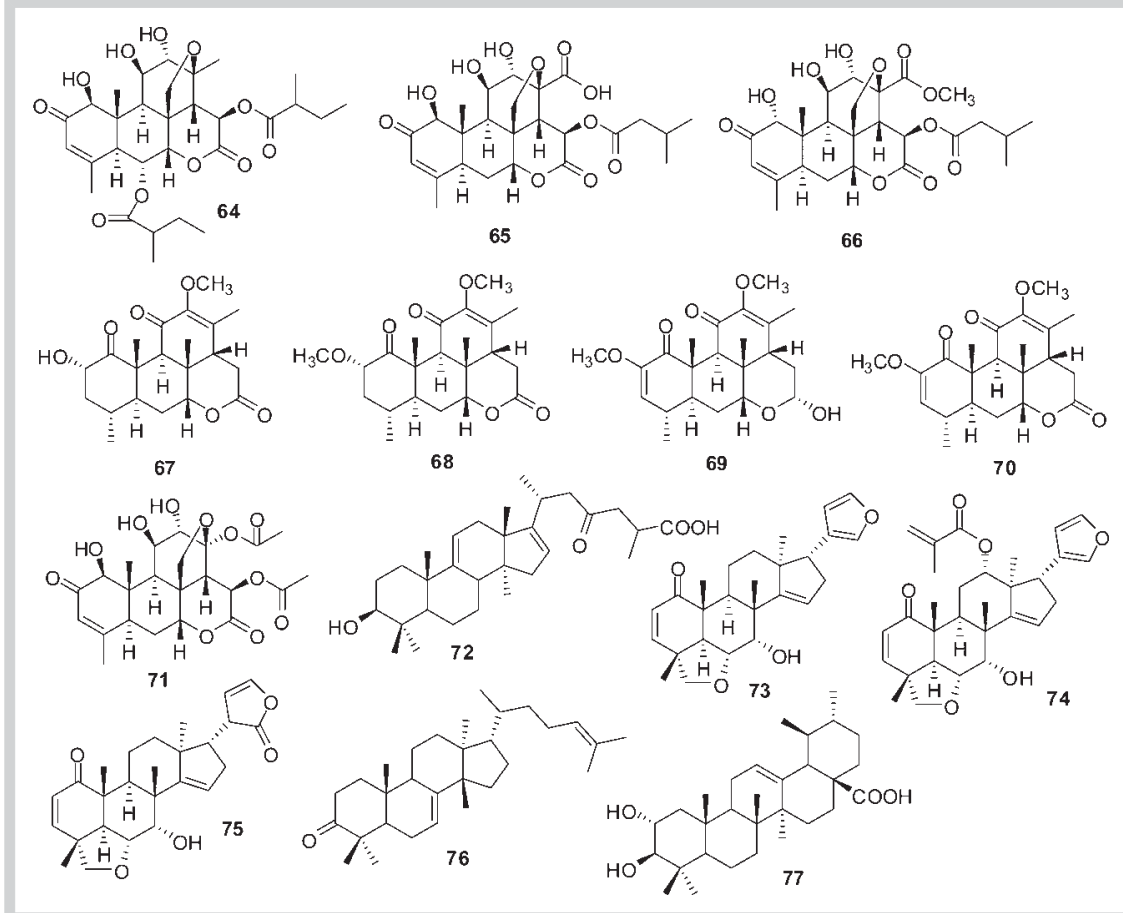

Fig. 8 Triterpenes with moderate or promising activity in vitro against various strains of Plasmodium falciparum.
Fractionation of the ethyl acetate extract of Carpesium cernuum $\mathrm{L}$. (Asteraceae) yielded four characterised sesquiterpenoid lactones among which 11(13)-dehydroivaxillin (57) and 11-epi-ivaxillin (58) exhibited antiplasmodial activity against D10 with $\mathrm{IC}_{50}$ values of 2.0 and $9.3 \mu \mathrm{M}$ [34].

In vivo antiplasmodial activity of $\mathbf{5 7}$ showed a suppression of parasitemia of $58.6 \%$ with a dose of $2 \mathrm{mg} / \mathrm{kg} /$ day in the four-day test [35].

\section{Diterpenes ( $\bullet$ Fig. 7)}

A new diterpene, 12-O-deacetyl-6-O-acetyl-19-acetyloxycoleon $\mathrm{Q}$ (59), and a known one (60) were isolated from the aerial parts of Anisochilus harmandii Doan (Lamiaceae) and exhibited antiplasmodial activity with $\mathrm{IC}_{50}$ values of 6.5 and $9.1 \mu \mathrm{M}$ on $\mathrm{K} 1$ [36]. A known compound, caniojane (61), was isolated from the roots of Jatropha integerrima Jacq. (Euphorbiaceae) and was evaluated for its antiplasmodial activity: $\mathrm{IC}_{50}$ of $9.6 \mu \mathrm{M}$ against $\mathrm{K} 1$ [37].

Baccharis dracunculifolia D.C. (Asteraceae) was shown to contain hautriwaic acid (62) and hautriwaic acid lactone (63) which had $\mathrm{IC}_{50}$ values of 9.0 and $2.5 \mu \mathrm{M}$, respectively, on D6 and 7.8 and $7.0 \mu \mathrm{M}$, respectively, on W2 [14].

\section{Triterpenes (๑ Fig. 8)}

A new quassinoid named simalikalactone E (64) was extracted from Quassia amara L. (Simaroubaceae) leaves and inhibited Plasmodium falciparum with $\mathrm{IC}_{50}$ values of $24 \mathrm{nM}$ on W2, $45 \mathrm{nM}$ on FcB1 and $68 \mathrm{nM}$ on F32 [38].
Two new quassinoids, delaumonones A (65) and B (66) were isolated from the bark of Laumoniera bruceadelpha Noot. (Simaroubaceae) and showed an antimalarial activity on 3D7 $\left(\mathrm{IC}_{50}=0.6\right.$ and $1.1 \mu \mathrm{M})$ [39].

Four other quassinoids were isolated from the dichloromethane extract of Quassia amara L. (Simaroubaceae): picrasin B (67), H-J (68-70). These compounds have antimalarial activities with $\mathrm{IC}_{50}$ values of, respectively, 0.8, 3.4, 2.6 and $4.2 \mu \mathrm{M}$ on W2 [40]. Isobrucein B (71) isolated from Picrolemma sprucei Hook. f. (Simaroubaceae) was tested for its antimalarial activity against the $\mathrm{K} 1$ strain $\left(\mathrm{IC}_{50}=2.1 \mathrm{nM}\right)$ [41].

Garcihombronane D (72) was obtained from Garcinia celebica L. (Clusiaceae) and showed an activity with an $\mathrm{IC}_{50}$ of $7.7 \mu \mathrm{M}$ on a Ghana strain [17].

Three new limonoids, ceramicines B-D (73-75), were isolated from the bark of Chisocheton ceramicus Miq. (Meliaceae). Ceramicines exhibited an antiplasmodial activity with $\mathrm{IC}_{50}$ values of $0.56,4.8$ and $5.1 \mu \mathrm{M}$, respectively, on 3D7 [42].

A phytochemical study of the stem bark of Vismia laurentii De Wild. (Clusiaceae) resulted in the isolation of a tetracyclic triterpene, tirucalla-7,24-dien-3-one (76) which showed antimalarial activity of $1.18 \mu \mathrm{M}$ against W2 [27].

Baccharis dracunculifolia D.C. (Asteraceae) was shown to contain $2 \alpha$-hydroxyursolic acid (77) which presented an $\mathrm{IC}_{50}$ of $6.8 \mu \mathrm{M}$ on D6 and $6.4 \mu \mathrm{M}$ on W2 [14]. 

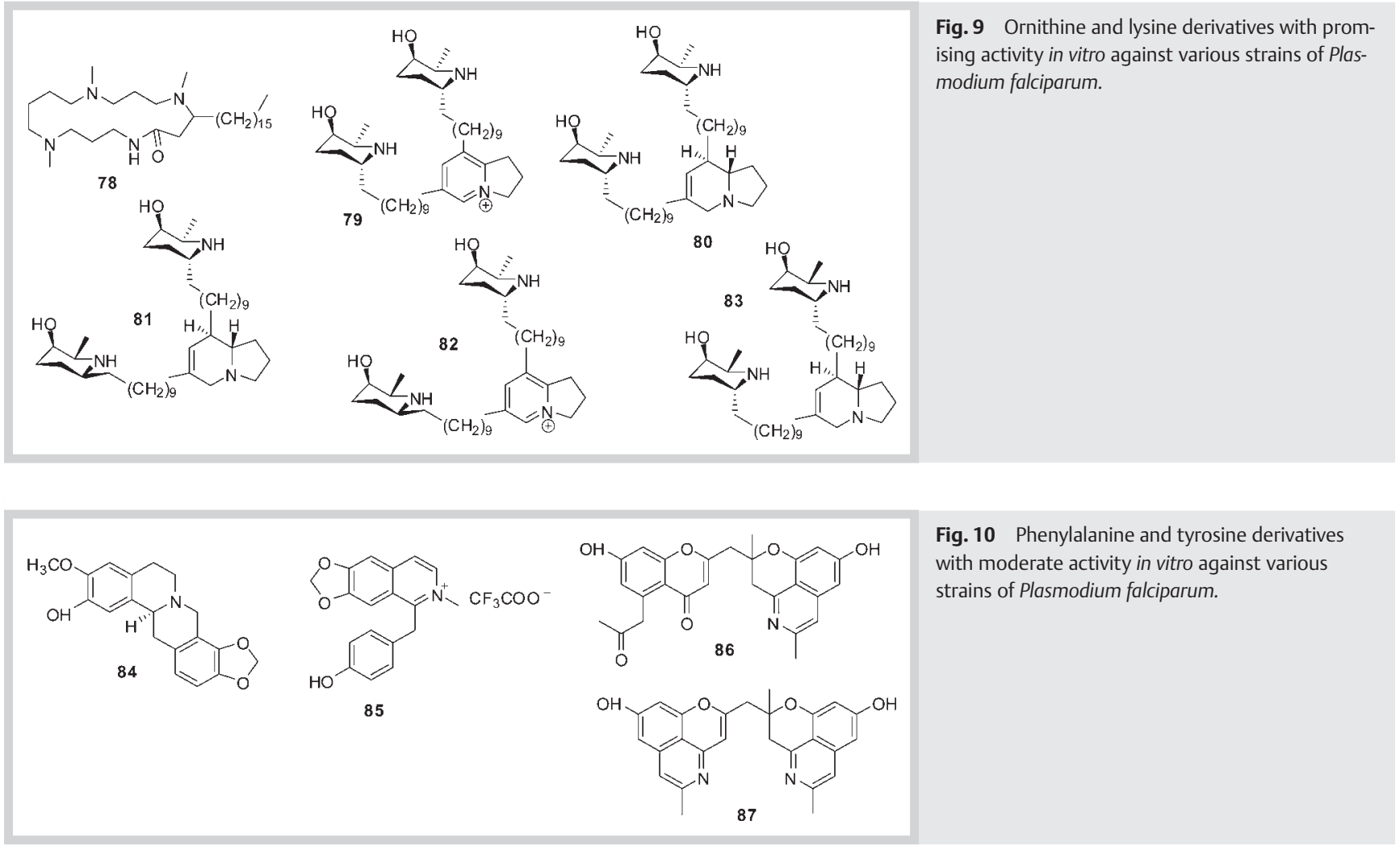

\section{Alkaloids}

Ornithine and lysine derivatives ( $\odot$ Fig. 9)

Researches on Albizia schimperiana Oliv. (Leguminosae) allowed the isolation of the new bioactive macrocyclic spermine alkaloid, namely 5,14-dimethylbudmunchiamine L1 (78). This compound demonstrated antimalarial activity against D6 and W2 with $\mathrm{IC}_{50}$ values of 0.27 and $0.34 \mu \mathrm{M}$ [43].

Four new indolizidines: prosopilosidine (79), prosopilosine (80), isoprosopilosine (81) and isoprosopilosidine (82) and a known one, juliprosopine (83) were isolated from Prosopis glandulosa Torrey var. glandulosa (Leguminosae). These compounds exhibited potent activity with $\mathrm{IC}_{50}$ values of $62,191,132,67$ and $350 \mathrm{nM}$, respectively, on D6 and 152, 366, 238, 192 and $604 \mathrm{nM}$, respectively, on W2. Prosopilosine also showed in vivo antimalarial activity, exhibiting $48 \%$ suppression of parasitemia at $2 \mathrm{mg} / \mathrm{kg} /$ day/i.p. against Plasmodium berghei after 3 days of treatment [44].

Phenylalanine and tyrosine derivatives ( $\odot$ Fig. 10)

A known alkaloid, cheilanthifoline (84), from Corydalis calliantha D.G. Long (Papaveraceae) showed antiplasmodial activitiy against TM4 and $\mathrm{K} 1$ strains with $\mathrm{IC}_{50}$ values of 2.8 and $3.8 \mu \mathrm{M}$, respectively [45].

The dichloromethane extract of Doryphora sassafras Endl. (Monimiaceae) was fractionated to obtain a quaternary benzylisoquinoline alkaloid, 1-(4-hydroxybenzyl)-6,7-methylenedioxy-2methylisoquinolinium trifluoroacetate (85) which presented an antiplasmodial activity of $4.4 \mu \mathrm{M}$ on Dd2 and 3.0 $\mu \mathrm{M}$ on 3D7 [46]. Two new dimeric alkaloids, cassiarins $\mathrm{D}(86)$ and $\mathrm{E}$ (87), which showed antiplasmodial activity against $3 \mathrm{D} 7 \quad\left(\mathrm{IC}_{50}=3.6\right.$ and $7.3 \mu \mathrm{M}$ ), were isolated from flowers of Cassia siamea Lam. (Caesalpinaceae) [23].
Tryptophane derivatives ( $\bigcirc$ Fig. 11)

Flinderole A (88) was isolated from Flindersia acuminata C.T. White (Rutaceae), flinderoles B-C (89-90) from F. amboinensis Poir., and isoborreverine (91) and dimethylisoborreverine (92) from $F$. fournieri Pancher \& Sebert. They have selective antimalarial activities with $\mathrm{IC}_{50}$ values of $1.42,0.15,0.34,0.32$ and $0.08 \mu \mathrm{M}$, respectively, on Dd2 while on cancer cells (HEK-293) their $\mathrm{IC}_{50}$ values were 19.97, 2.13, 9.75, 8.99 and $4.09 \mu \mathrm{M}$, respectively [47]. Three new alkaloids, alstiphyllanines B-D (93-95), were isolated from Alstonia macrophylla Wall. (Apocynaceae) and showed antiplasmodial activity against 3D7 with $\mathrm{IC}_{50}$ values of $0.6,10.0$ and $4.5 \mu \mathrm{M}$, respectively [48].

\section{Other $\mathrm{N}$-containing compounds ( $\odot$ Fig. 12)}

Studies on the $\mathrm{CH}_{2} \mathrm{Cl}_{2} / \mathrm{MeOH}$ extract from the roots of the Australian tree Mitrephora diversifolia Miq. (Annonaceae) resulted in the purification of the known 5-hydroxy-6-methoxyonychine (96) which displayed $\mathrm{IC}_{50}$ values of 9.9 and $11.4 \mu \mathrm{M}$, respectively, on 3D7 and Dd2 [49].

\section{Other Metabolites (O Fig. 13)}

The flower extracts of Goniothalamus laoticus (Fin. \& Gagnep.) Bân (Annonaceae) were fractionated to obtain a styryllactone, (+)-3-acetylaltholactone (97). This compound was evaluated for its antiplasmodial activity against $\mathrm{K} 1\left(\mathrm{IC}_{50}=9.5 \mu \mathrm{M}\right)$ but it showed cytotoxicity against human cancer cell lines with $\mathrm{IC}_{50}$ values of 10.6, 3.3 and $6.6 \mu \mathrm{M}$, respectively, on KB, BC1 and NCIH187 [50].

A linear polyacetylenic diol (98) was isolated from Bidens pilosa $\mathrm{L}$. (Asteraceae), and exhibited antiplasmodial properties in vitro with $\mathrm{IC}_{50}$ of $1.8 \mu \mathrm{M}$ on FCR-3 as well as antimalarial activity by in- 


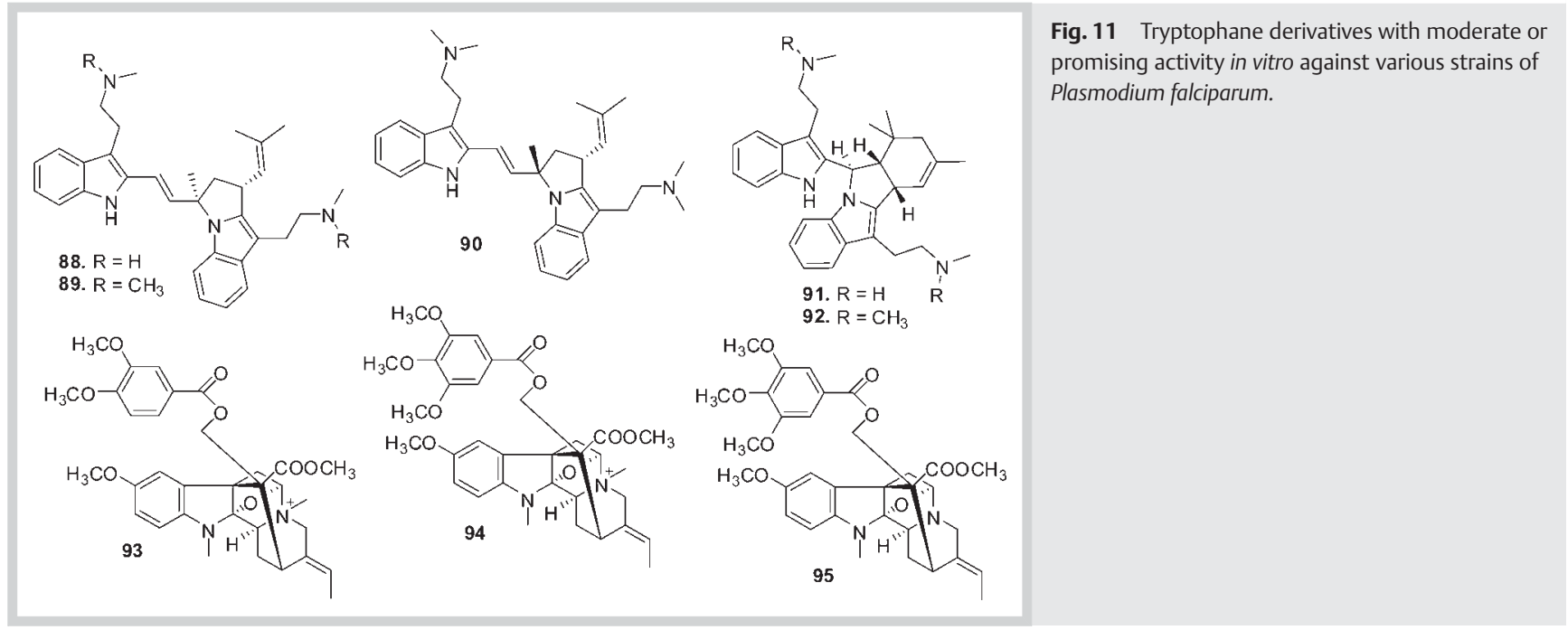

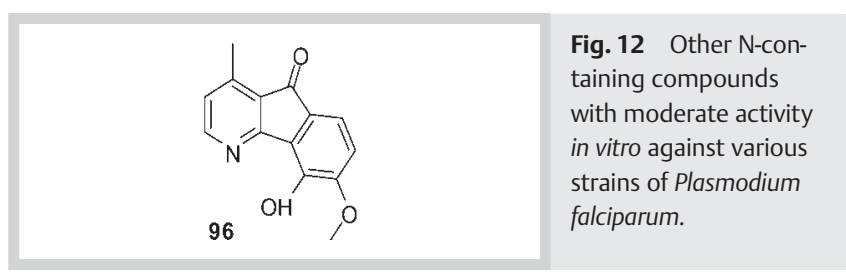

travenous injection in vivo, which was carried out in mice infected with the Plasmodium berghei NK-65 strain. The average parasitemia of $32.8 \%$ in the control red blood cells was decreased significantly to $12.1 \%$ by the administration of $0.8 \mathrm{mg} / \mathrm{kg} /$ day of the compound for four days [51].

\section{Discussion and Conclusions \\ $\nabla$}

In traditional medicine, traditional healers use plants for the treatment of malaria or several symptoms of the disease. This review focusing on publications of 2009 shows that some promising new antimalarial compounds can be isolated by the ethnopharmacological and bioguided fractionation approaches. Various extracts of plants were fractionated to obtain 146 compounds which were evaluated for antimalarial activity in vitro. Among them, 41 possessed low $\left(11<\mathrm{IC}_{50}<50 \mu \mathrm{M}\right), 65$ moderate $\left(2<\mathrm{IC}_{50}\right.$ $<11 \mu \mathrm{M}$ ) and 31 promising $\left(\mathrm{IC}_{50}<2 \mu \mathrm{M}\right)$ activity in vitro against various strains of Plasmodium falciparum which is responsible for the most severe form of malaria. The activity of some of these compounds was tested against various cell lines, normal or cancer cells, but only a few of them for their in vivo antimalarial activity. Nevertheless, in these cases, the promising in vitro activities could be confirmed by in vivo tests. Among them, a phenolic compound: 6-(8'Z-pentadecenyl)-salicylic acid, a sesquiterpene lactone: 11(13)-dehydroivaxillin, a tryptophane derivative: prosopilosine, and a linear polyacetylenic diol seem promising.

Moreover, ellagic acid already isolated and tested in vitro before 2009 with an $\mathrm{IC}_{50}$ of $0.5 \mu \mathrm{M}$ on D6 and $0.3 \mu \mathrm{M}$ on W2 with no cytotoxicity, displayed interesting antimalarial efficacy in vivo with a parasitemia reduction of $50 \%$ at $1.0 \mathrm{mg} / \mathrm{kg} /$ day by the intraperitoneal route. This compound could be an interesting candidate for further development $[52,53]$.

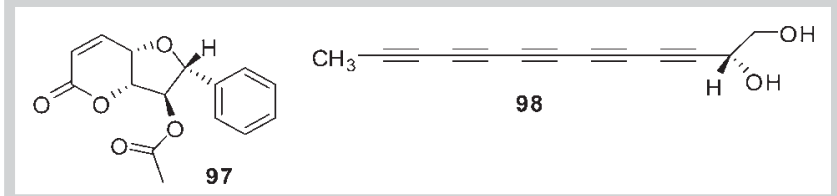

Fig. 13 Other metabolites with moderate or promising activity in vitro against various strains of Plasmodium falciparum.

Among the compounds we reviewed, only a few of them exhibited a good activity and should be considered as lead compounds for further investigations ( Table 1). In 2009, most of the highly active compounds were found in the alkaloid and terpene chemical classes, which was also the case in 2005-2008 (- Fig. 14). The same trend was observed when considering families from which active compounds were isolated ( Fig. 15). Most active alkaloids published in 2009 were isolated from the Leguminosae and Rutaceae families [10]. In our previous review, Leguminosae was also identified as a family allowing isolation of a significant number of active alkaloids, while Rutaceae was not found to be particulary interesting although it is a family whose activity is often due to the presence of alkaloids [6].

The more active triterpenes were obtained from Simaroubaceae which seem to have been well studied in 2009 and were not identified as an interesting family in 2005-2008. However, other reviews confirmed that the active antimalarial molecules of the Simaroubaceae are mainly quassinoids [6,9]. Quassinoids often displayed anticancer activity but the antimalarial activity does not seem to be correlated with the cytotoxicity [54].

When considering highly active compounds and families from which they were isolated and comparing with the results of 2005-2008, we observed that in 2009 no highly active diterpene was isolated, although this class was pointed out to be very interesting in 2005-2008. The same is observed with the Caesalpinaceae family from which they were isolated. This may be explained by the fact that one team focused in 2005-2008 on diterpenes from Caesalpinaceae leading to Kalauni et al. [55] and Linn et al. [56]. 
Table 1 Tested compounds presenting promising activity with $\mathrm{IC}_{50}<2 \mu \mathrm{M}$.

\begin{tabular}{|c|c|c|c|c|}
\hline Chemical class & Family & Plant & Compound & $\mathrm{IC}_{50}(\mu \mathrm{M})$ \\
\hline Alkaloids & Rutaceae & Flindersia acuminata C. T. White & Flinderole A & $1.42(\mathrm{Dd} 2)$ \\
\hline Akaloids & Rutaceae & Flindersia amboinensis Poir. & Flinderole B & $0.15(\mathrm{Dd} 2)$ \\
\hline Alkaloids & Rutaceae & Flindersia amboinensis Poir. & Flinderole C & $0.34(\mathrm{Dd} 2)$ \\
\hline Alkaloids & Rutaceae & Flindersia fournieri Pancher \& Sebert & Isoborreverine & $0.32(\mathrm{Dd} 2)$ \\
\hline Alkaloids & Rutaceae & Flindersia fournieri Pancher \& Sebert & Dimethylisoborreverine & $0.08(\mathrm{Dd} 2)$ \\
\hline Alkaloids & Apocynaceae & Alstonia macrophylla Wall. & Alstiphyllanine B & $0.60(3 \mathrm{D} 7)$ \\
\hline Alkaloids & Leguminosae & Albizia schimperiana Oliv. & 5,14-Dmethylbudmunchiamine L1 & $\begin{array}{l}0.27(\mathrm{D} 6) \\
0.34(\mathrm{~W} 2)\end{array}$ \\
\hline Alkaloids & Leguminosae & Prosopis glandulosa Torrey & Prosopilosidine & $\begin{array}{l}0.06(\mathrm{D} 6) \\
0.15(\mathrm{~W} 2)\end{array}$ \\
\hline Alkaloids & Leguminosae & Prosopis glandulosa Torrey & Prosopilosine & $\begin{array}{l}0.19(\mathrm{D} 6) \\
0.37(\mathrm{~W} 2)\end{array}$ \\
\hline Alkaloids & Leguminosae & Prosopis glandulosa Torrey & Isoprosopilosine & $\begin{array}{l}0.13(\mathrm{D} 6) \\
0.24(\mathrm{~W} 2)\end{array}$ \\
\hline Alkaloids & Leguminosae & Prosopis glandulosa Torrey & Isoprosopilosidine & $\begin{array}{l}0.07(\mathrm{D} 6) \\
0.19(\mathrm{~W} 2)\end{array}$ \\
\hline Alkaloids & Leguminosae & Prosopis glandulosa Torrey & Juliprosopine & $\begin{array}{l}0.35(\mathrm{D} 6) \\
0.60(\mathrm{~W} 2)\end{array}$ \\
\hline Coumarins & Apiaceae & Angelica purpuraefolia Chung & (+)-4'-Decanoyl-cis-khellactone & 1.5 (D10) \\
\hline Flavonoids & Moraceae & Artocarpus champeden Spreng. & Artopeden & $0.11(3 \mathrm{D} 7)$ \\
\hline Other metabolites & Asteraceae & Bidens pilosa $\mathrm{L}$. & Polyacetylenic diol & 1.8 (FCR-3) \\
\hline $\begin{array}{l}\text { Other phenolic } \\
\text { derivatives }\end{array}$ & Clusiaceae & Cratoxylum cochinchinense Blume & Vismione B & $1.86(\mathrm{~K} 1)$ \\
\hline Quinones & Boraginaceae & Cordia globifera W.W.Sm & Cordiachrome C & $0.8(\mathrm{~K} 1)$ \\
\hline Quinones & Boraginaceae & Cordia globifera W.W. Sm & Cordiaquinol C & $1.2(\mathrm{~K} 1)$ \\
\hline Quinones & Rhamnaceae & Scutia myrtina Kurz & Scutianthraquinone A & $\begin{array}{l}1.23 \text { (Dd2) } \\
1.2(\text { FCM29) }\end{array}$ \\
\hline Quinones & Rhamnaceae & Scutia myrtina Kurz & Scutianthraquinone B & $\begin{array}{l}1.14 \text { (Dd2) } \\
5.4(\text { FCM29) }\end{array}$ \\
\hline Quinones & Clusiaceae & Vismia laurentii De Wild. & Vismiaquinone $\mathrm{A}$ & $1.42(\mathrm{~W} 2)$ \\
\hline Sesquiterpenes & Cyperaceae & Scleria striatonux De Wild. & Okundoperoxide & $\begin{array}{l}1.8 \text { (W2) } \\
1.8 \text { (D6) } \\
5.6 \text { (K1) } \\
5.0 \text { (NF54) }\end{array}$ \\
\hline Sesquiterpenes & Asteraceae & $\begin{array}{l}\text { Distephanus angulifolius (DC.) } \\
\text { H. Rob. \& B. Kahn }\end{array}$ & $\begin{array}{l}\text { (6S,7R,8S)-14-Acetoxy-8-[2-hydroxymethylacrylate]-15- } \\
\text { helianga-1(10),4,11(13)-trien-15-al-6,12-olide }\end{array}$ & $\begin{array}{l}1.90(\mathrm{D} 10) \\
3.24(\mathrm{~W} 2)\end{array}$ \\
\hline Sesquiterpenes & Asteraceae & $\begin{array}{l}\text { Distephanus angulifolius (DC.) } \\
\text { H. Rob. \& B. Kahn }\end{array}$ & $\begin{array}{l}\text { (5R,6R,7R,8S,10S)-14-Acetoxy-8-[2-hydroxymethyl- } \\
\text { acrylate]-elema-1,3,11(13)-trien-15-al-6,12-olide }\end{array}$ & $\begin{array}{l}1.55(\mathrm{D} 10) \\
2.10(\mathrm{~W} 2)\end{array}$ \\
\hline Triterpenes & Simaroubaceae & Quassia amara L. & Simalikalactone E & $\begin{array}{l}0.02 \text { (W2) } \\
0.05 \text { (FcB1) } \\
0.07 \text { (F32) }\end{array}$ \\
\hline Triterpenes & Simaroubaceae & Quassia amara L. & Picrasin B & $0.80(\mathrm{~W} 2)$ \\
\hline Triterpenes & Meliaceae & Chisocheton ceramicus Miq. & Ceramicine B & $0.56(3 \mathrm{D} 7)$ \\
\hline Triterpenes & Simaroubaceae & Laumoniera bruceadelpha Noot. & Delaumonone A & $0.6(3 \mathrm{D} 7)$ \\
\hline Triterpenes & Simaroubaceae & Laumoniera bruceadelpha Noot. & Delaumonone B & 1.1 (3D7) \\
\hline Triterpenes & Simaroubaceae & Picrolemma sprucei Hook. f. & Isobrucein B & $0.002(\mathrm{~K} 1)$ \\
\hline Triterpenes & Clusiaceae & Vismia laurentii De Wild. & Tirucalla-7,24-dien-3-one & $1.18(\mathrm{~W} 2)$ \\
\hline
\end{tabular}

Three of the most active sesquiterpenes are lactones and were obtained from a plant of the Asteraceae family as it was the case for the "famous" artemisinin.

Among families from which most highly active compounds were isolated in 2005-2008, Menispermaceae and Asphodelaceae are not represented in 2009 while from Moraceae, only one interesting flavonoid (artopeden A) was isolated.

These observations and comparisons show that it is often difficult to assess general rules concerning interesting classes of compounds or interesting families as it may depend highly on the activity of specific research groups. Nevertheless, we can indicate that during 2009, alkaloids from the Leguminosae and Rutaceae families, quassinoids from Simaroubaceae and well-known sesquiterpene lactones from Asteraceae were described as interesting antimalarial compounds with original structures which could be considered as lead compounds for new drugs against resistant malaria.

\section{Supporting information}

Tested phenolic derivatives, terpenic compounds, alkaloids and other metabolites presenting low or no activity in vitro against various strains of Plasmodium falciparum (Tables 1S-4S) are available as Supporting Information. 


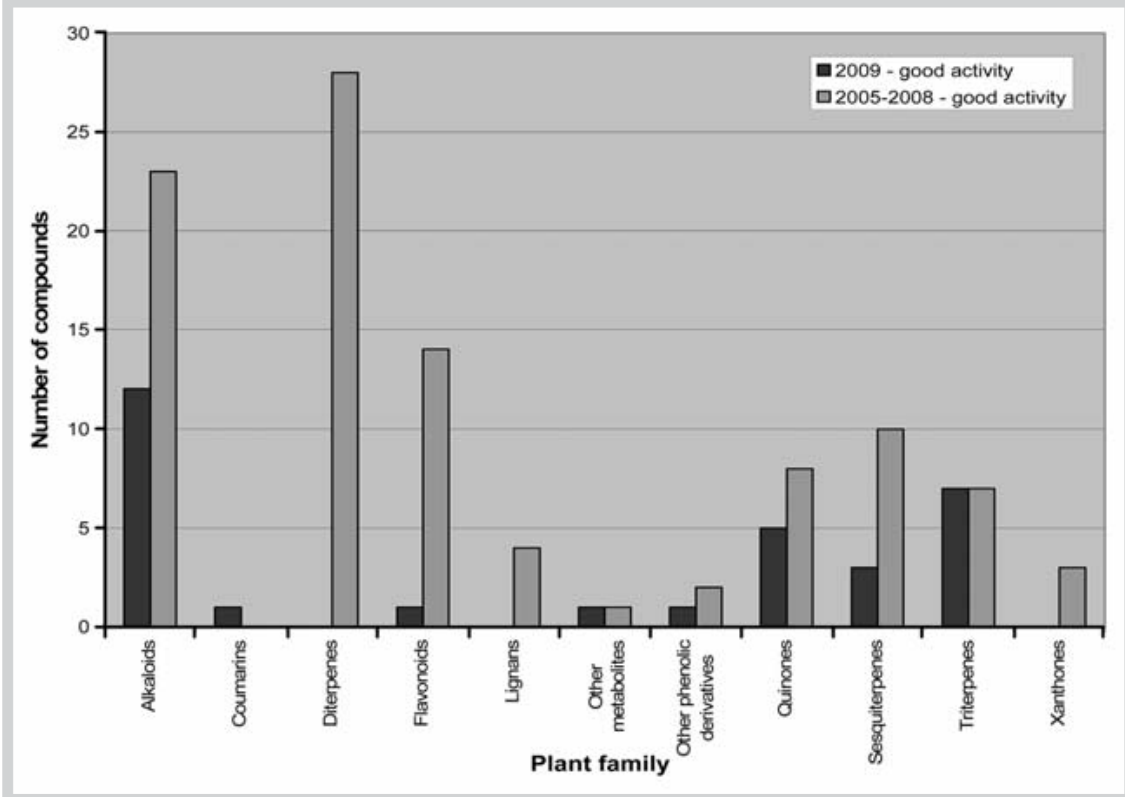

Fig. 14 Number of compounds with good activity $\left(\mathrm{IC}_{50}<2 \mu \mathrm{M}\right)$ in vitro against various strains of Plasmodium falciparum, classified according to their chemical classes.

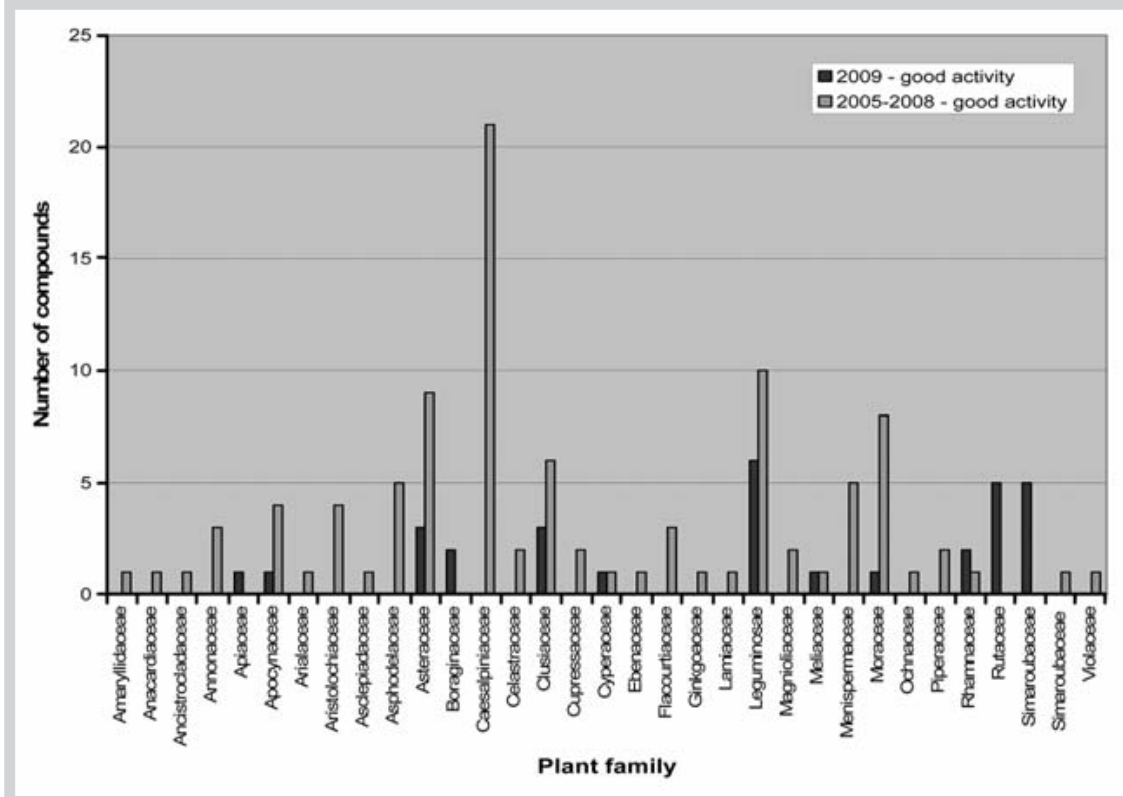

Fig. 15 Number of compounds with good activity $\left(\mathrm{IC}_{50}<2 \mu \mathrm{M}\right)$ in vitro against various strains of Plasmodium falciparum, classified according to the plant family from which they were isolated.

\section{References}

1 Bilia AR. Non-nitrogenous plant-derived constituents with antiplasmodial activity. Nat Prod Commun 2006; 1: 1181-1204

2 Caniato R, Puricelli L. Review: natural antimalarial agents (1995-2001). Crit Rev Plant Sci 2003; 22: 79-105

3 Fournet A, Munoz V. Natural products as trypanocidal, antileishmanial and antimalarial drugs. Curr Top Med Chem 2002; 2: 1215-1238

4 Phillipson JD. Natural-products as drugs. Trans R Soc Trop Med Hyg 1994; 88: $17-19$

5 Saxena S, Pant N, Jain DC, Bhakuni RS. Antimalarial agents from plant sources. Curr Sci 2003; 85: 1314-1329

6 Schwikkard S, van Heerden FR. Antimalarial activity of plant metabolites. Nat Prod Rep 2002; 19: 675-692

7 Wright CW. Plant derived antimalarial agents: new leads and challenges. Phytochem Rev 2005; 4: 55-61

8 Mambu L, Grellier P. Antimalarial compounds from traditionally used medicinal plants. In: Colegate SM, Molyneux RJ, editors. Bioactive natural products. Detection, isolation and structural determination, 2nd edition. Boca Raton, USA: CRC Press; 2008: 491-529

9 Kaur K, Jain M, Kaur T, Jain R. Antimalarials from nature. Bioorg Med Chem 2009; 17: 3229-3256
10 Bero J, Frederich M, Quetin-Leclercq J. Antimalarial compounds isolated from plants used in traditional medicine. J Pharm Pharmacol 2009; 61: 1401-1433

11 dos Santos DAP, Braga PAD, da Silva MFDF, Fernandes JB, Vieira PC, Magalhaes AF, Magalhaes EG, Marsaioli AJ, Moraes VRD, Rattray L, Croft SL. Anti-African trypanocidal and antimalarial activity of natural flavonoids, dibenzoylmethanes and synthetic analogues. J Pharm Pharmacol 2009; 61: 257-266

12 Muiva LM, Yenesew A, Derese S, Heydenreich M, Peter MG, Akala HM, Eyase F, Waters NC, Mutai C, Keriko JM, Walsh D. Antiplasmodial $\beta$-hydroxydihydrochalcone from seedpods of Tephrosia elata. Phytochem Lett 2009; 2: 99-102

13 Wahyuni TS, Ekasari W, Widyawaruyanti A, Hirasawa Y, Morita H, Zaini $\mathrm{NC}$. Artopeden A, a new antiplasmodial isoprenylated flavone from $\mathrm{Ar}$ tocarpus champeden. Heterocycles 2009; 79: 1121-1126

14 da Silva AA, Resende DO, Fukui MJ, Santos FF, Pauletti PM, Cunha WR, Silva MLA, Gregorio LE, Bastos JK, Nanayakkara NPD. In vitro antileishmanial, antiplasmodial and cytotoxic activities of phenolics and triterpenoids from Baccharis dracunculifolia D. C. (Asteraceae). Fitoterapia 2009; 80: 478-482 
15 Zelefack F, Guilet D, Fabre N, Bayet C, Chevalley S, Ngouela S, Lenta BN, Valentin A, Tsamo E, Dijoux-Franca MG. Cytotoxic and antiplasmodial xanthones from Pentadesma butyracea. J Nat Prod 2009; 72: 954-957

16 Laphookhieo S, Maneerat W, Koysomboon S. Antimalarial and cytotoxic phenolic compounds from Cratoxylum maingayi and Cratoxylum cochinchinense. Molecules 2009; 14: 1389-1395

17 Elfita E, Muharni M, Latief M, Darwati D, Widiyantoro A, Supriyatna S, Bahti HH, Dachriyanus D, Cos P, Maes L, Foubert K, Apers S, Pieters L. Antiplasmodial and other constituents from four Indonesian Garcinia spp. Phytochemistry 2009; 70: 907-912

18 Chung IM, Ghimire BK, Kang EY, Moon HI. Antiplasmodial and cytotoxic activity of khellactone derivatives from Angelica purpuraefolia Chung. Phytother Res 2010; 24: 469-471

19 Flores N, Jimenez IA, Gimenez A, Ruiz G, Gutierrez D, Bourdy G, Bazzocchi IL. Antiparasitic activity of prenylated benzoic acid derivatives from Piper species. Phytochemistry 2009; 70: 621-627

20 Chung IM, Seo SH, Kang EY, Park WH, Moon HI. Anti-malarial activity of 6-(8'Z-pentadecenyl)-salicylic acid from Viola websteri in mice. Malar J 2009; 8: 151

21 Lee SJ, Park WH, Moon HI. Bioassay-guided isolation of antiplasmodial anacardic acids derivatives from the whole plants of Viola websteri Hemsl. Parasitol Res 2009; 104: 463-466

22 Roumy V, Fabre N, Portet B, Bourdy G, Acebey L, Vigor C, Valentin A, Moulis $C$. Four anti-protozoal and anti-bacterial compounds from Tapirira guianensis. Phytochemistry 2009; 70: 305-311

23 Oshimi S, Deguchi J, Hirasawa Y, Ekasari W, Widyawaruyanti A, Wahyuni TS, Zaini NC, Shirota O, Morita H. Cassiarins C-E, antiplasmodial alkaloids from the flowers of Cassia siamea. J Nat Prod 2009; 72: 18991901

24 Marti G, Eparvier V, Moretti C, Susplugas S, Prado S, Grellier P, Retailleau $P$, Gueritte F, Litaudon M. Antiplasmodial benzophenones from the trunk latex of Moronobea coccinea (Clusiaceae). Phytochemistry 2009; 70: 75-85

25 Seephonkai P, Sangdee A, Bunchalee P, Pyne SG. Cytotoxic and antiplasmodial compounds from the roots of Strophioblachia fimbricalyx. J Nat Prod 2009; 72: 1892-1894

26 Hou Y, Cao S, Brodie PJ, Callmander MW, Ratovoson F, Rakotobe EA, Rasamison VE, Ratsimbason M, Alumasa JN, Roepe PD, Kingston DGI. Antiproliferative and antimalarial anthraquinones of Scutia myrtina from the Madagascar forest. Bioorg Med Chem 2009; 17: 2871-2876

27 Noungoue DT, Chaabi M, Ngouela S, Antheaume C, Boyom FF, Gut J, Rosenthal PJ, Lobstein A, Tsamo E. Antimalarial compounds from the stem bark of Vismia laurentii. Z Naturforsch (C) 2009; 64: 210-214

28 Dettrakul S, Surerum S, Rajviroongit S, Kittakoop P. Biomimetic transformation and biological activities of globiferin, a terpenoid benzoquinone from Cordia globifera. J Nat Prod 2009; 72: 861-865

29 Efange SMN, Brun R, Wittlin S, Connolly JD, Hoye TR, McAkam T, Makolo FL, Mbah JA, Nelson DP, Nyongbela KD, Wirmum CK. Okundoperoxide, a bicyclic cyclofarnesylsesquiterpene endoperoxide from Scleria striatinux with antiplasmodial activity. J Nat Prod 2009; 72: 280-283

30 Henchiri H, Bodo B, Deville A, Dubost L, Zourgui L, Raies A, Grellier P, Mambu $L$. Sesquiterpenoids from Teucrium ramosissimum. Phytochemistry 2009; 70: 1435-1441

31 Lategan CA, Campbell WE, Seaman T, Smith PJ. The bioactivity of novel furanoterpenoids isolated from Siphonochilus aethiopicus. J Ethnopharmacol 2009; 121: 92-97

32 Pedersen MM, Chukwujekwu JC, Lategan CA, Van Staden J, Smith PJ, Staerk $D$. Antimalarial sesquiterpene lactones from Distephanus angulifolius. Phytochemistry 2009; 70: 601-607

33 Nour AMM, Khalid SA, Kaiser M, Brun R, Abdallah WE, Schmidt TJ. The antiprotozoal activity of sixteen Asteraceae species native to Sudan and bioactivity-guided isolation of xanthanolides from Xanthium brasilicum. Planta Med 2009; 75: 1363-1368

34 Chung IM, Moon HI. Antiplasmodial activities of sesquiterpene lactone from Carpesium cernum. J Enzym Inhib Med Chem 2009; 24: 131-135

35 Kim JJ, Chung IM, Jung JC, Kim MY, Moon HI. In vivo antiplasmodial activity of 11(13)-dehydroivaxillin from Carpesium ceruum. J Enzym Inhib Med Chem 2009; 24: 247-250

36 Lekphrom R, Kanokmedhakul S, Kanokmedhakul K. Bioactive diterpenes from the aerial parts of Anisochilus harmandii. Planta Med 2010; 76 : 726-728

37 Sutthivaiyakit S, Mongkolvisut W, Prabpai S, Kongsaeree P. Diterpenes, sesquiterpenes, and a sesquiterpene-coumarin conjugate from Jatropha integerrima. J Nat Prod 2009; 72: 2024-2027
38 Cachet N, Hoakwie F, Bertani S, Bourdy G, Deharo E, Stien D, Houel E, Gornitzka H, Fillaux J, Chevalley S, Valentin A, Jullian V. Antimalarial activity of simalikalactone E, a new quassinoid from Ouassia amara L. (Simaroubaceae). Antimicrob Agents Chemother 2009; 53: 4393-4398

39 Oshimi S, Takasaki A, Hirasawa Y, Hosoya T, Awang K, Hadi AHA, Ekasar $W$, Widyawaruyanti A, Morita $H$. Delaumonones A and B, new antiplasmodial quassinoids from Laumoniera bruceadelpha. Chem Pharm Bull 2009; 57: 867-869

40 Houel E, Bertani S, Bourdy G, Deharo E, Jullian V, Valentin A, Chevalley S, Stien D. Quassinoid constituents of Quassia amara L. leaf herbal tea. Impact on its antimalarial activity and cytotoxicity. J Ethnopharmacol 2009; 126: 114-118

41 Silva ECC, Cavalcanti BC, Amorim RCN, Lucena JF, Quadros DS, Tadei WP, Montenegro RC, Costa-Lotufo LV, Pessoa C, Moraes MO, Nunomura RCS, Nunomura SM, Melo MRS, Andrade-Neto VF, Silva LFR, Vieira PPR, Pohlit $A M$. Biological activity of neosergeolide and isobrucein B (and two semi-synthetic derivatives) isolated from the Amazonian medicinal plant Picrolemma sprucei (Simaroubaceae). Mem Inst Oswaldo Cruz 2009; 104: 48-55

42 Mohamad K, Hirasawa Y, Litaudon M, Awang K, Hadi AHA, Takeya K, Ekasari W, Widyawaruyanti A, Zaini NC, Morita H. Ceramicines B-D, new antiplasmodial limonoids from Chisocheton ceramicus. Bioorg Med Chem 2009; 17: 727-730

43 Samoylenko V, Jacob MR, Khan SI, Zhao JP, Tekwani BL, Midiwo JO, Walker LA, Muhammad I. Antimicrobial, antiparasitic and cytotoxic spermine alkaloids from Albizia schimperiana. Nat Prod Commun 2009; 4: 791-796

44 Samoylenko V, Ashfaq MK, Jacob MR, Tekwani BL, Khan SI, Manly SP, Joshi VC, Walker LA, Muhammad I. Indolizidine, antiinfective and antiparasitic compounds from Prosopis glandulosa var. glandulosa. J Nat Prod 2009; 72: 92-98

45 Wangchuk P, Bremner JB, Samten, Rattanajak R, Kamchonwongpaisan S. Antiplasmodial agents from the Bhutanese medicinal plant Corydalis calliantha. Phytother Res 2010; 24: 481-485

46 Buchanan MS, Davis RA, Duffy S, Avery VM, Quinn RJ. Antimalarial benzylisoquinoline alkaloid from the rainforest tree Doryphora sassafras. J Nat Prod 2009; 72: 1541-1543

47 Fernandez LS, Buchanan MS, Carroll AR, Feng YJ, Quinn RJ, Avery VM. Flinderoles A-C: antimalarial bis-indole alkaloids from Flindersia species. Org Lett 2009; 11: 329-332

48 Hirasawa Y, Arai H, Zaima K, Oktarina R, Rahman A, Ekasari W, Widyawaruyanti A, Indrayanto G, Zaini NC, Morita $H$. Alstiphyllanines A-D, indole alkaloids from Alstonia macrophylla. J Nat Prod 2009; 72: 304-307

49 Mueller D, Davis RA, Duffy S, Avery VM, Camp D, Quinn RJ. Antimalarial activity of azafluorenone alkaloids from the Australian tree Mitrephora diversifolia. J Nat Prod 2009; 72: 1538-1540

50 Lekphrom R, Kanokmedhakul S, Kanokmedhakul K. Bioactive styryllactones and alkaloid from flowers of Goniothalamus laoticus. J Ethnopharmacol 2009; 125: 47-50

51 Tobinaga S, Sharma MK, Aalbersberg WGL, Watanabe K, Iguchi K, Naru $K$, Sasatsu M, Waki S. Isolation and identification of a potent antimalarial and antibacterial polyacetylene from Bidens pilosa. Planta Med 2009; 75: 624-628

52 Soh PN, Witkowski B, Olagnier D, Nicolau ML, Garcia-Alvarez MC, Berry $A$, Benoit-Vical F. In vitro and in vivo properties of ellagic acid in malaria treatment. Antimicrob Agents Chemother 2009; 53: 1100-1106

53 Verotta L, Dell'Agli M, Giolito A, Guerrini M, Cabalion P, Bosisio E. In vitro antiplasmodial activity of extracts of Tristaniopsis species and identification of the active constituents: ellagic acid and 3,4,5-trimethoxyphenyl-(6'-O-galloyl)-O-beta-D-glucopyranoside. J Nat Prod 2001; 64: 603-607

54 Phillipson JD, Wright CW. Antiprotozoal agents from plant sources. Planta Med 1991; 57: S53-S59

55 Kalauni SK, Awale S, Tezuka Y, Banskota AH, Linn TZ, Asih PBS, Syafrud$\operatorname{din} D$, Kadota S. Antimalarial activity of cassane- and norcassane-type diterpenes from Caesalpinia crista and their structure-activity relationship. Biol Pharm Bull 2006; 29: 1050-1052

56 Linn TZ, Awale S, Tezuka Y, Banskota AH, Kalauni SK, Attamimi F, Ueda J, Asih PBS, Syafruddin D, Tanaka K, Kadota S. Cassane- and norcassanetype diterpenes from Caesalpinia crista of Indonesia and their antimalarial activity against the growth of Plasmodium falciparum. J Nat Prod 2005; 68: 706-710 